\title{
Relationship Students from a Broken Home Family with Deviant Behavior in Vocational High School YBKP3 Garut
}

\author{
Iwan Shalahuddin*, Indra Maulana and Theresia Eriyani \\ Faculty of Nursing Universitas Padjadjaran, Jl. Raya Bandung-Sumedang KM 21, 45363, West Java, Indonesia; \\ *Correspondence: Shalahuddin.iwan@gmail.com \\ Type of the Paper (Article)
}

Received: January 21, 2019; Accepted: January 31, 2019; Published: February 3, 2019

https://doi.org/10.29253/achnr.2019.13914

\begin{abstract}
Referring to the Broken home families are families that arise due to the absence of affection and mutual respect, lack of communication and a sense of disagreement among family members, so that broken children do not meet the attention and supervision of parents The broken home effect is very influential on children, especially children in adolescence, because adolescence is a period where children are looking for self-identity, there is a change from the phase of children to the adult phase, are labile and tend to be emotional, so children show attitude against parents, and make mischief outside the home or at school. The general objective of this study was to determine the relationship between students from broken families with deviant behavior at schools in YBKP3 Garut Vocational School in 2015. By identifying the characteristics of students from broken families, identifying deviant behaviors of students from broken families in school and knowing the relationship between students from families broken home with deviant behavior at school. This research belongs to correlational descriptive study which aimed at finding out the relationship between students from broken home families and deviant behavior at school. Populations in this research were 58 students. The instrument in this research was an observation about deviant behavior for students who have broken home family. Data analysis used univariate and bivariate analysis with chi-square. The findings of the research showed that there was a relationship between students from broken home families and deviant behavior at school. Broken home families mainly resulted in teenager delinquency or deviant behavior at school. It could conclude that there was a relationship between students from broken home families and deviant behavior at school. Broken home families can become the main factor of misbehavior at school. Meanwhile, divorced parents are the most significant reason for the students' deviant behavior (85.7\%).
\end{abstract}

Keywords: broken home; deviant behavior; students 


\section{Introduction}

Family as a social system and the small group consists of individuals who have close relations and are dependent on each other as a single unit in achieving the purposes, (Ali \& SKM: 2010). The family has five functions; affective, socialization, economic, reproductive, and health care.

Supposing that affective and social functions in the family do not work well, the children would get negative impacts. Children would prefer to be with their friends which consequently if they make friends with good people, they will be good ones; contrarily, if they are friends who behave badly, they will also get worse influences. This can happen to the children who are from broken families (Ngafifi, M: 2014).

A family turns into broken when there are not found affection, respect, communication among other family members, and each family member tend to have a lot of conflicts. As a result, the children from broken families do not have enough attention and control of their parents, (Purnamasari, S. E, 2010). The effects of broken home are very influential to the children, especially for adolescents. In their period, they are still looking for self-identity and in transition from adolescence to adult life. Also, they are so labile and emotional that they show an attitude against their parents and become delinquent outside home and school (Husni, M. A, \& Purwaningsih, I. E, 2013).

This statement is confirmed by the research result of Swastika \& Retnaningsih (2012), naughty teens from broken families are caused by divorced parents and lack of communication among family members. Of 30 respondents, 23 teenagers (76.6\%) from broken home families show deviant behavior. Forms of their deviant behavior were lying (100\%) and ditching school (98.7\% or 26 respondents).

Based on the preliminary study in Vocational School YBKP3 Garut in 2015, there were found students with broken home families. One of the school counselors in that school revealed that eleventh-grade students were in the highest number of broken home problems; 50 students from the total of 170 students (29.41\%). This was due to they had more authority and self-confidence as seniors, were more courageous to the teachers, and were not yet concentrating on their study such as twelve graders. Most of them showed several deviant behaviors such as ditching school, being impolite to the teachers and reluctant in doing the assignment, and fighting with other students.

According to the background of the problem mentioned above, the research problem formulated is "What is the relationship between students from broken home families and deviant behavior in Vocational High School YBKP3 Garut in 2015?" The purpose of this research is to find out the relationship between students from broken home families and deviant behavior in Vocational High School YBKP3 Garut in 2015 by means of identifying the students' characteristics and deviant behavior from broken home families and ascertaining the relationship between students from broken home families and deviant behavior. The scope of this research is to observe the teenager behaviors of Vocational High School YBKP3 Garut students towards the broken home families and limited in the number of samples and time constraints.

A family is the smallest unit of the society consisting of the head of family and some other people who live in the same house and depend on each other (Ali \& SKM: 2010). According to the government regulations number 21 of 1995 chapter 1 paragraph 1, a family is defined as the smallest unit of society consisting of husband and wife, or parents and their children, or father and his children, or mother and her children.

As mentioned earlier, family has five basic functions. The affective function of the family relates to the internal functioning of family which is the basic strength of family. Socialization function is the process of individual development and change which results in social interaction and in learning to play role in society. Reproductive function serves to ensure the continuation of offspring and to improve human source. Economic function is intended to meet family members' needs such as food, clothes, and houses. Family also requires finance source. Family care function is to provide health care to family member to prevent or to cure the disease. The family also determines whether family member who experiences health problem need help from professional health staff or not. This ability greatly influences the state of someone's health in the family (Ali \& SKM: 2010).

The term adolescence derives from the word adolescere which means "grow" or "grow into adult". It has a broader meaning and covers mental, emotional, and physical maturity. Adolescence is divided into 3 phases namely early adolescence (10 - 13 years), middle adolescence (14 - 17 years), and late adolescence (18 - 22 years) (Santrock, 2009). 
The roles of parents in communicating with teenagers are limited to certain topics such as education, material at school, health, and finance. While father's communication role as the biggest resource person for adolescents is about career problems (61\%) and education (52\%), the roles of mother's communication are required when the teenagers want to talk about health (84\%) and finance (69\%). In terms of social problem topic or choosing partners including sexual problems, teenagers tend to ask their friends more (80\%) (Zuhri: 2012).

Adolescence is a critical period of development during the transition from childhood to adulthood. It is also a period when they are looking for identity, experiencing tough development and a lot of confusion. In this period, they need more understanding and help from people whom they love or are close to them especially their parents or families. At this time, affective and social function of family plays a very important role.

One of the factors that lead to broken home families is divorce. It is the reality of husband and wife life in which there is no more compassion of the faltering marriage and finally, it cannot make the marriage last (Setyaningsih, T. S, 2011). When husband and wife are about to divorce, their relationship is getting tenuous because either husband or wife does not have intention to build good communication. The relationship shows unfamiliar situation and the separation that is about to happen. In that situation, there will be a shift of affective and social function in the family due husband and wife do not feel any intimate sense of togetherness. Finally, the shift meaning of affective and social function in a family which play role as basis strength of one's family will be broken. When this happens, the happiness of family especially the children will be sacrificed because their psychological function will no longer be fulfilled. This situation is later called broken home families (Rohmatul Ulya, I. T. A, 2010).

The absence of communication often occurs to the communities which know each other and are especially bound by certain relationship. The problems among the communities will not get more difficult if the people in the communities do not truly know each other and the communities only last in a temporary situation. If the parents do not give chance for their children to communicate or to talk about the necessary thing, the children would never want to share their stories or to open themselves up. They tend to stay quiet which at last will make them frustrated and annoyed.

Juvenile delinquency occurs because of lack of communication among parents and children; besides, the parents are so busy with their own activities that they show no affection to their children. This situation will give a negative impact to the family when affective and social function of the family such as mutual care and close interaction among family members are not found. Consequently, the children become neglected and alone. In fact, the parents' attention by giving certain material pleasure is not enough for children. Communication to the children cannot be replaced by expensive and good material, it has a significant role (Surbakti, F. B, 2009).

The initial conflict among family members often occurs when the husband becomes selfish and stubborn in expressing his opinion; on the other hand, the wife also insists on what she wants no matter what. Conflict can also happen if there are found different opinions or principles among family members. This conflict causes hatred among family members and it also makes the children irritated (Wahyuni, S.D, 2010).

When the children often watch the parents' dispute, they will get used to it and show less respect to their parents. Children will adopt behaviors or habits as shown by parents in their lives, so they will learn to rebel or fight when they have different principles or opinions with other people. Behavior is a range of actions and mannerism made by an organism which can be indirectly or directly observed. Attitude is a syndrome or collection of symptoms in responding to the stimuli towards certain objects that involve mind, feeling, and others. (Notoatmodjo, 2010).

Deviation is an action that deviates from the prevailing norms in a social system and creates effort from the authorities to correct the deviant or abnormal behavior (Duarsa, 2010).

Therefore, deviant behavior at school is all deviating actions from the norms prevailing at school, resulting in the efforts of those who have authority at school to correct that deviant behavior.

\section{Research Methods}

This research used a correlational descriptive method because its purpose was to acquire the relationship between students from broken home families and their deviant behavior at school. the 
instrument in this research is an observation about deviant behavior for students who had family broken home family

The population in this research was 58 students. They were taken from the whole eleventh grade students of Vocational High School YBPK3 Garut, their ages were from 14 to 17 and they were from broken home families.

Non-Random Sampling with proportional sampling technique was applied in selecting the sample. Several criteria have been made for the samples, such as the students who have 1 from these 3 criteria: (Broken home students due to the divorced parents, Broken home students due to not living with the parents or their parents are busy working, broken home students because of inharmonious family or lack of communication and attention or parents' disputes.

Data collected in the form of secondary data were taken from students' attendance list and personal books that cover variables. Data were analyzed using univariate and bivariate analysis with chi-square test, Chi-Square test was applied in nominal scale data to find out whether there was a relationship between dependent and independent variable or not. They were carefully reviewed to obtain concrete data on deviant behavior carried out by respondents.

\section{Results and Discussion}

Due to the research method used was descriptive, the statistical data analysis was processed in form of proportion test. Therefore, the median value as the assessment standard was obtained as the result of maximum score (4) for each item multiplied by the total number of attitude questions which had been tested for validity and reliability and its result was divided by 2 .

Chi-Square test was applied in nominal scale data to find out whether there was a relationship between the dependent and independent variable or not.

Univariate Analysis in this analysis will produce frequency distribution and percentage of each variable. Univariate analysis in this study is the data on the characteristics of respondents, the causes of broken home, and broken home student behavior.

Tabel 1. Frequency Distribution of Respondent Characteristics.

\begin{tabular}{|c|c|c|}
\hline Variables & $\begin{array}{c}\text { Total } \\
(n=50)\end{array}$ & $\%$ \\
\hline \multicolumn{3}{|l|}{ Age } \\
\hline 17 & 47 & 94 \\
\hline 16 & 3 & 6 \\
\hline \multicolumn{3}{|l|}{ Sex } \\
\hline Male & 40 & 80 \\
\hline Female & 10 & 20 \\
\hline \multicolumn{3}{|l|}{ Class } \\
\hline Nursing Assistant Class A & 8 & 16 \\
\hline Nursing Assistant Class B & 5 & 10 \\
\hline Pharmaceutical Class A & 5 & 10 \\
\hline Pharmaceutical Class B & 7 & 14 \\
\hline Pharmaceutical Class C & 13 & 26 \\
\hline Pharmaceutical Class D & 12 & 24 \\
\hline
\end{tabular}

As seen in Table 1, 47 respondents (94\%) were in the ages of 17,40 respondents were male students, and nearly all the respondents were from pharmaceutical class, 37 respondents $(76 \%)$.

Table 2 showed the respondent frequency in terms of the causes of broken home. Most of all respondents or 28 people (56\%) revealed that it was caused by inharmonious family (lack of communication and attention, a lot of disputes) and the least respondents or 7 people (14\%) thought the broken family was caused by divorced parents. 


\begin{tabular}{|c|c|c|}
\hline Variable & $\begin{array}{c}\text { Total } \\
(n=50)\end{array}$ & $\%$ \\
\hline Divorced Parents & 7 & 14 \\
\hline Not living with the parents or busy working parents & 15 & 30 \\
\hline \multicolumn{3}{|c|}{ Inharmonious family (lack of communication and attention, and a } \\
\hline lot of disputes) & 28 & 56 \\
\hline
\end{tabular}

The table 3 provided the respondent frequency in terms of broken home students' behavior. Almost half of the respondents, 13 people (26\%) were ditching school and a few of them, 5 respondents (10\%) neglect their homework, and the other eight respondents (26\%) did both (ditching school and neglecting the homework).

Table 3. Frequency of Broken Home Students' Behavior.

\begin{tabular}{lcc}
\hline Variables & $\begin{array}{c}\text { Total } \\
(\mathbf{n = 5 0 )}\end{array}$ & $\mathbf{\%}$ \\
\hline Ditching School & 13 & 26 \\
Neglecting the homework & 5 & 10 \\
Both & 8 & 16 \\
Not Behaving Badly & 24 & 48 \\
\hline
\end{tabular}

Bivariate Analysis in this analysis the relationship of broken home will be known to the occurrence of deviant behavior in students which contains the results of analytic tests of the characteristics of broken home with behavior and the chi-square test results characteristic of broken home with deviant behaviour.

Table 4. Analytical Test Result of Broken Home Behavior Characteristics.

\begin{tabular}{lccc}
\hline \multicolumn{1}{c}{ Broken Home Characteristics } & \multicolumn{2}{c}{ Behavior } & Total \\
\cline { 2 - 3 } Divorced parents & $6(85.7 \%)$ & $1(14.3 \%)$ & $7(100.0 \%)$ \\
$\begin{array}{l}\text { Not living with the parents or busy working } \\
\text { parents }\end{array}$ & $4(26.7 \%)$ & $11(73.3 \%)$ & $15(100.0 \%)$ \\
$\begin{array}{l}\text { Inharmonious family (lack of communication } \\
\text { and attention, and a lot of disputes) }\end{array}$ & $16(57.1 \%)$ & $12(42.9 \%)$ & $28(100.0 \%)$ \\
\hline \multicolumn{1}{c}{ Total } & $26(52.0 \%)$ & $24(48.0 \%)$ & $50(100.0 \%)$ \\
\hline
\end{tabular}


Table 5. Chi-Square Test Result of Broken Home Characteristics with Deviant Behavior.

\begin{tabular}{|c|c|c|c|c|c|}
\hline \multirow[b]{2}{*}{ Characteristics of Broken Home } & \multicolumn{3}{|c|}{$\begin{array}{c}\text { Broken Home Students' Deviant } \\
\text { Behaviors }\end{array}$} & \multirow[b]{2}{*}{$\begin{array}{l}\text { Total } \\
\text { N (\%) }\end{array}$} & \multirow[b]{2}{*}{ p-Value } \\
\hline & $\begin{array}{l}\text { Ditching } \\
\text { School } \\
\text { n (\%) }\end{array}$ & $\begin{array}{c}\text { Neglecting } \\
\text { homework } \\
\text { n (\%) }\end{array}$ & $\begin{array}{l}\text { Both } \\
\text { n (\%) }\end{array}$ & & \\
\hline Divorced Parents & $2(33 \%)$ & $1(17 \%)$ & $3(50 \%)$ & $6(100.0 \%)$ & \\
\hline $\begin{array}{l}\text { Not living with parents or busy } \\
\text { working parents }\end{array}$ & $1(33 \%)$ & $2(67 \%)$ & $0(0 \%)$ & $3(100.0 \%)$ & \\
\hline $\begin{array}{l}\text { Inharmonious family (lack of } \\
\text { communication and attention, and a } \\
\text { lot of disputes) }\end{array}$ & $10(59 \%)$ & $2(12 \%)$ & $5(29 \%)$ & $17(100.0 \%)$ & 0,025 \\
\hline Total & $13(47 \%)$ & $5(26 \%)$ & $8(27 \%)$ & $26(100.0 \%)$ & \\
\hline
\end{tabular}

The Relationship between broken home family and students' deviant behavior

As seen in Table 4 and 5, the statistical test result between two variables, broken home family and students' deviant behavior in Vocational High School YBKP3 Garut, the $p$-Value obtained was 0.025 and the significant level $(\alpha)$ was 0.05 . This means that $0,025<0,05$, Ho rejected and $H i$ accepted. From the value obtained, it concludes that there is a relationship between broken home family and deviant behavior. The statistical test result also implies that broken home family or students from broken home family can be the main factor of deviant behavior.

Broken home family was the main cause of adolescents' delinquency or deviation at school. This is caused by children's first relationship was firstly begun with their parents. They lived and developed with their parents or other family members. According to Schaie \& Willis (2010), the family is the foundation and formation of children's education and behavior.

In the case of parents' divorce, the children are not usually involved in the divorce. They merely accept the decision of their parents to divorce without even know the problems. To avoid misunderstanding, the parents are expected to give a simple explanation to the children about why the divorce happens. It is hoped that the children will understand that divorce is the only way that the parents should take. Therefore, the children will have no negative assumption on the parents' divorce, (Sukmawati, E, 2015).

As second parents at school, the teachers, especially homeroom teachers are expected to give more attention and control to the students' divorced parents. Listening to the students when they share problems could be one of the attention given by the teachers. It will be a better idea if the homeroom teachers in every semester can gather, discuss, identify the students' family problems that can affect them to study at school. After that, those problems could be further discussed by counselor teachers so that the teachers can anticipate if some of students behave badly, (Aroma \& Suminar: 2012).

Living with other people because parents are too busy with their work, having family economic problem, not being able to educate the children or other causes are several things that can make children neglected. This feeling will make children think that their parents do not even care nor want them. These factors have actually triggered children's deviation or delinquency, (Schaie \& Willis:2010).

Children commit a delinquent act because they do not get enough attention at home. Instead, they get attention and recognition outside house, such as from their teachers or friends, even though, the things they do to attract attention are actually deviant behavior, (Schaie \& Willis: 2010). This statement is in line with research conducted by Puspitawati (2002). In her research, she found out that "the feeling to get social recognition and parental attention turned out to be one of the factors that triggered juvenile delinquency." This explained that most of adolescent who committed deviant behavior was merely to get social recognition and attention from parents.

Parent-teacher meeting should be regularly done, especially for the parents of troubled students. In the meeting, the parents and teachers can share or even invite expert people to do parenting training. Therefore, teachers and parents can intensively cooperative in supervising the troubled students to avoid the deviation, (Mas'udi A, 2015). 
Parent-child reciprocal communication is very important to improve so that the parents are able to understand what the children have done, the children can also know what their parents expect them to be. Only good communication and attention can the children feel more secured and also the parents can supervise them well. Parent-child communication in terms of education is also important to avoid the children commit deviant acts at home or at school, (Schaie \& Willis: 2010).

Lack of attention and communication can make children feel neglected. The parents will not know the deep problem their children face. The children will also feel as if they themselves fought to solve the problems. In fact, in that situation, children need parents to support them, (Schaie \& Willis: 2010). Therefore, to get what the children are needed, they make friends that can support or give attention to them. If they have more friends who behave badly, the children will get influence to commit bad things too.

The only thing that can be done by the parents is to improve the quality of communication and attention. Open parent-child communication can make the relationship stronger and the children needs of love and attention can be given by the parents. Besides, it is suggested that the parents should not have any conflict in front of the children because it can make them stressed, (Sutrisno, S, 2011).

The results of Ayu $R$ (2013) show that the application of self-management strategies (self-management) can help students reduce delinquency in victims of broken home identified from several students. This can be seen from the decrease in the juvenile delinquency score of the broken home compared to the implementation of self-management strategies. Students who initially have high adolescents who are victims of broken home can lower their scores lower, with the way they monitor themselves to control and reinforce members so that delinquency behavior is not repeated.

\section{Conclusion and Recommendation}

Based on the research findings obtained by bivariate analysis, it can draw some conclusions that there is a relationship between students from broken-home families and deviant behavior at school. This implies that students with broken-home background can be a factor of deviant behavior at school. In this research, most of the respondents with broken-home family background are caused by inharmonious family, lack of communication and attention, a lot of parent conflicts with the percentage of $56 \%$ in total. The biggest impact of respondents' deviant behavior is divorced parents with a percentage of $85.7 \%$.

This research can be further developed in terms of a different setting. If this research focused on the relationship between broken-home students and deviant behavior at school. For the next research, it can be observed outside the school. The teachers especially school counselor and homeroom teachers are expected to give attention and supervision more to the students from broken-home families. In each semester, homeroom teachers and school counselors are expected to discuss and to identify students' problem that can impact their learning activities. By doing so, it can anticipate the students to commit deviant behavior. It is necessary to have regular teacher-parent conference both classically and personally. The teachers and parents can cooperate to increase the quality of supervision and attention to the troubled students to avoid deviant behavior. For health service institution, especially for those who work in counseling guidance, this research can be a reference to conduct counseling concerning on broken-home teenagers' deviant behavior.

\section{References}

Ali, H. Z., \& SKM, M. (2010). Pengantar keperawatan keluarga. EGC.

Aroma, I. S., \& Suminar, D. R. (2012). Hubungan antara tingkat kontrol diri dengan kecenderungan perilaku kenakalan remaja. Jurnal Psikologi Pendidikan dan Perkembangan, 1(2), 1-6.

Ayu R, D. (2013). Penerapan Strategi Pengelolaan Diri (Self Management) untuk Mengurangi Kenakalan Remaja Korban Broken Home. Jurnal BK Unesa, 3(1).

Duarsa, N. (2010). Buku Ajar Tumbuh Kembang Remaja dan Permasalahannya.

Husni, M. A., \& Purwaningsih, I. E. (2013). Identitas diri ditinjau dari kelekatan remaja pada orang tua di SMKN 4 Yogyakarta. Jurnal Spirits, 4(1), 43-53.

Mas'udi, A. (2015). Pola Penanganan Guru Pai Dan Bk Terhadap Penyimpangan Moralitas Siswa Studi Kasus Di Smk Saraswati dan Smk Diponegoro Salatiga Tahun Pelajaran 2013-2014 (Doctoral dissertation, Thesis, Program Pascasarjana Institut Agama Islam Negeri (IAIN) Salatiga). 
Ngafifi, M. (2014). Kemajuan teknologi dan pola hidup manusia dalam perspektif sosial budaya. Jurnal Pembangunan Pendidikan: Fondasi dan Aplikasi, 2(1).

Notoatmodjo, S. (2010). Etika dan Hukum Kesehatan. Rineka Cipta, Jakarta.

Purnamasari, S. E. (2010). Hubungan antara harga diri dengan sikap terhadap perilaku seksual pranikah pada remaja dari keluarga broken home. Psycho Idea, 8(2).

Puspitawati, H. (2008). Pengaruh komunikasi keluarga, lingkungan teman dan sekolah terhadap kenakalan pelajar dan nilai pelajaran pada sekolah menengah di Kota Bogor.

Rohmatul Ulya, I. T. A. (2010). Perilaku Minat Belajar Remaja Pada Keluarga Broken Home (Doctoral dissertation, UIN Sunan Ampel Surabaya).

Santrock, J. W. (2009). Psicologia educacional. AMGH Editora.

Schaie, K. W., \& Willis, S. L. (Eds.). (2010). Handbook of the Psychology of Aging. Academic Press.

Setyaningsih, T. S. (2011). Pendekatan Konseling Realita Dalam Mengubah Konsep Diri Negatif Siswa Broken Home (Penelitian Pada Siswa SMP Negeri 2 Bantarbolang Pemalang Tahun Ajaran 2010/2011) (Doctoral dissertation, Universitas Negeri Semarang).

Sukmawati, E. (2015). Dampak biopsikososial dan spiritual anak korban perceraian orang tua: Studi kasus pada perceraian yang diakibatkan oleh perselingkuhan dan kekerasan dalam rumah tangga.

Surbakti, F. B. (2009). Kenalilah anak remaja anda. Elex Media Komputindo.

Sutrisno, S. (2011). Peranan orangtua dalam pembinaan akhlak pada siswa kelas VII Madrasah Tsanawiyah Negeri 2 Wonogiri tahun pelajaran 2010/2011 (Doctoral dissertation, IAIN Walisongo).

Swastika, I., \& Retnaningsih, R. (2012). Resiliensi Pada Remaja yang Mengalami Broken Home.

Wahyuni, S. D. (2010). Konflik dalam Keluarga Single Parent (Studi Deskriptif Kualitatif tentang Konflik dalam Keluarga Single Parent di Desa Pabelan Kecamatan Kartasura Sukoharjo) (Doctoral dissertation, Universitas Sebelas Maret).

Zuhri, M. (2012). Pola Komunikasi Orang Tua Kandung Terhadap Anak Remaja yang Mengalami Depresi. Jurnal Ilmu Komunikasi, 1(2). 